\title{
Obliczenia cieplne dla doboru urządzeń ogrzewania i klimatyzacji kabin operatorów pojazdów szynowych
}

\begin{abstract}
$W$ artykule przedstawiono obliczenia cieplne kabin maszynisty (motorniczego) pojazdów szynowych, oddzielnie dla uktadu ogrzewania i dla uktadu klimatyzacji kabiny. Przedstawione obliczenia moga być pomocne przy doborze urzadzeń grzewczych i klimatyzacyjnych do pojazdów nowych oraz modernizowanych. Sposób postępowania przy obliczeniach zostat oparty o najnowsze normy europejskie, karty UIC oraz TSI dla podsystemu „Tabor kolejowy - lokomotywy i tabor pasażerski” systemu kolei konwencjonalnych.
\end{abstract}

\section{Wprowadzenie}

Współczesne pojazdy szynowe dużych prędkości obowiązkowo wyposażane są w układy klimatyzacji kabin maszynisty oraz wnętrza pasażerskiego $\mathrm{z}$ racji braku otwieralnych okien $\mathrm{w}$ składzie pociągu. Pojazdy dużych prędkości nie posiadają otwieralnych okien w związku z powstawaniem dużej amplitudy fal ciśnienia podczas mijania się dwóch pociągów lub wjazdu pociagu do tunelu. Taka różnica mogłaby uszkodzić narząd słuchu człowieka.

Nowe oraz modernizowane pojazdy szynowe konwencjonalne są coraz częściej wyposażane w układy klimatyzacji. Zapewniają one wyższy komfort jazdy dla pasażerów i maszynisty pociagu. W stosunku do klasycznych układów wentylacyjnych są bardziej wydajne i skuteczniej osuszają powietrze w kabinie maszynisty oraz $\mathrm{w}$ przedziałach osobowych, co jest ważne podczas okresów o zwiększonej wilgotności powietrza, np. w trakcie opadów deszczu lub śniegu.

Zabudowa układu klimatyzacji zależy jednak od specyfikacji zamawiającego pojazd. Koszt zakupu odpowiednich urządzeń zwiększa całkowity koszt wytworzenia nowego pojazdu lub koszt przebudowy pojazdu modernizowanego. Podczas modernizacji jednym $\mathrm{z}$ ważniejszych problemów jest znalezienie miejsca pod zabudowę jednostki klimatyzującej, jeśli dotychczas nie była przewidziana do używania w pojeździe.

Niniejszy artykuł przedstawia sposób obliczeń, opartych na aktualnych normach i kartach UIC, w wyniku których wyznacza się minimalną niezbędną moc chłodniczą lub grzewczą, potrzebną do zapewnienia określonych warunków komfortu jazdy. Przez dobór urządzenia odpowiedniego do rzeczywistych potrzeb można zoptymalizować nakłady finansowe, które trzeba ponieść na jego zakup.

\section{Wymagania normatywne}

Parametry komfortu klimatyzowanych kabin maszynisty zostały zdefiniowane $\mathrm{w}$ normach $[4,5,6]$. Kabiny operatorskie podzielono na dwie kategorie, przedstawione w tabeli 1.

Podzial kabin maszynisty według normy PN-EN 14813-1:2006 [5]

Tabela 1

\begin{tabular}{|l|c|c|}
\cline { 2 - 3 } \multicolumn{1}{c|}{} & Kategoria A & Kategoria B \\
\hline Objętość kabiny & $\geq 9 \mathrm{~m}^{3}$ & $<9 \mathrm{~m}^{3}$ \\
\hline $\begin{array}{l}\text { Średni czas przebywania } \\
\text { maszynisty w kabinie }\end{array}$ & $>60 \mathrm{~min}$ & $\leq 60 \mathrm{~min}$ \\
\hline
\end{tabular}

Układy klimatyzacji, wentylacji oraz ogrzewania kabiny maszynisty powinny spełniać następujące warunki:

- ogrzanie kabiny od $0{ }^{\circ} \mathrm{C}$ do $18{ }^{\circ} \mathrm{C}$ maksymalnie w ciagu $1 \mathrm{~h}$;

- zmiana temperatury w kabinie o $1 \mathrm{~K} \mathrm{w}$ mniej niż $15 \mathrm{~min}$;

- schłodzenie kabiny do temperatury $27^{\circ} \mathrm{C}$ w mniej niż 1,5 h;

- wentylacja kabiny świeżym powietrzem min. $\mathrm{V}_{\min }=30 \mathrm{~m}^{3} / \mathrm{h}$ na osobę (ilość powietrza zapewniająca utrzymanie stężenia tlenku oraz dwutlenku węgla na poziomie niezagrażającym zdrowiu lub życiu obsługi).

Według normy PN-EN 13129-1:2004 [4] wszystkie państwa europejskie zostały przydzielone do poszczególnych stref temperaturowych w zależności od długości i temperatur pory letniej lub zimowej. Minimalne temperatury w porze zimowej i maksymalne w porze letniej dla poszczególnych stref temperaturowych zostały przedstawione w tabeli 2 . 
Wartości temperatur ekstremalnych dla poszczególnych stref temperaturowych Europy

Tabela 2

\begin{tabular}{|c|c|c|}
\hline Strefa & $\begin{array}{c}\text { Min. temp. ze- } \\
\text { wnetrzna } \mathrm{T}_{\mathrm{z}} \\
\text { (zima) }\end{array}$ & $\begin{array}{c}\text { Max. temp. ze- } \\
\text { wnętrzna } \mathrm{T}_{\mathrm{z}} \\
\text { (lato) }\end{array}$ \\
\hline I & $-10^{\circ} \mathrm{C}$ & $+40^{\circ} \mathrm{C}$ \\
\hline II & $-20^{\circ} \mathrm{C}$ & $+35^{\circ} \mathrm{C}$ \\
\hline III & $-40^{\circ} \mathrm{C}$ & $+28^{\circ} \mathrm{C}$ \\
\hline
\end{tabular}

W zależności od strefy temperaturowej i dla przedstawionych w tabeli 1. kategorii kabin maszynisty w normie PN-EN 14813-1:2006 [5] zostały określone maksymalne wartości temperatur wnętrza, które mogą być osiagnięte $\mathrm{w}$ kabinie $\mathrm{w}$ porze letniej $\mathrm{w}$ przypadku obecności w niej obsługi, przy założeniu minimalnego wymaganego nawiewu powietrza. Wspomniane wartości temperatur zostały przedstawione w tabeli 3 .

Maksymalna dopuszczalna wartość temperatury we wnętrzu kabiny maszynisty w porze letniej w zależności od jej kategorii

Tabela 3

\begin{tabular}{|c|c|c|}
\hline & \multicolumn{2}{|c|}{ Max. temp. wnętrza kabiny $\mathrm{T}_{\mathrm{w}}$} \\
\hline Strefa & Kategoria $\mathrm{A}$ & Kategoria $\mathrm{B}$ \\
\hline $\mathrm{I}$ & $+27^{\circ} \mathrm{C}$ & $+30^{\circ} \mathrm{C}$ \\
\hline II & $+26^{\circ} \mathrm{C}$ & $+28^{\circ} \mathrm{C}$ \\
\hline III & $+22^{\circ} \mathrm{C}$ & $+24^{\circ} \mathrm{C}$ \\
\hline
\end{tabular}

Dla pory zimowej norma PN-EN 148131:2006 [5] zaleca, aby temperatura wnętrza kabiny dla wszystkich stref temperaturowych i dla obu kategorii kabin wynosiła $\mathrm{T}_{\mathrm{w}}>+18^{\circ} \mathrm{C}$.

Podział państw europejskich na poszczególne strefy temperaturowe w zależności od lokalnych warunków klimatycznych został przedstawiony w tabeli 4.

W celu ukazania przykładu obliczeń przyjmuje się następujące parametry kabiny maszynisty:

Wymiary (długość x szerokość x wysokość): 2500 x $2000 \times 2500 \mathrm{~mm}$,

Objętość: $12,50 \mathrm{~m}^{3}$ (kategoria A),

Powierzchnia szyby bocznej: $0,6 \mathrm{~m}^{2}$,

Powierzchnia szyby czołowej: $3,5 \mathrm{~m}^{2}$,

Współczynnik przenikania ciepła dla zastosowanych szyb: $k_{\mathrm{sz}}=6 \mathrm{~W} / \mathrm{m}^{2} \mathrm{~K}$,

Kraj eksploatacji: Polska.

\section{Obliczenia cieplne kabiny maszynisty dla urzą- dzeń ogrzewania}

\subsection{Lączne straty ciepla}

W celu obliczenia strat ciepła dla doboru odpowiedniego urządzenia do ogrzewania kabiny, należy pominąć wpływ obecności człowieka oraz dopływ
Strefy temperaturowe Europy dla pory zimowej oraz letniej

Tabela 4

\begin{tabular}{|c|c|c|}
\cline { 2 - 3 } \multicolumn{1}{c|}{} & \multicolumn{2}{c|}{ Strefa } \\
\hline Kraj & $\begin{array}{c}\text { Pora } \\
\text { zimowa }\end{array}$ & $\begin{array}{c}\text { Pora } \\
\text { letnia }\end{array}$ \\
\hline Austria & II & II \\
\hline Belgia & II & II \\
\hline Bułgaria & II & II \\
\hline Czechy & II & II \\
\hline Chorwacja & II & II \\
\hline Dania & II & II \\
\hline Francja & II & II \\
\hline Finlandia & III & III \\
\hline Grecja & I & I \\
\hline Niemcy & II & II \\
\hline Węgry & II & II \\
\hline Irlandia & I & III \\
\hline Włochy & II & I \\
\hline Luksemburg & II & II \\
\hline Holandia & II & II \\
\hline Norwegia & III & III \\
\hline Polska & III & II \\
\hline Portugalia & I & I \\
\hline Rumunia & II & II \\
\hline Serbia ${ }^{*}$ & II & II \\
\hline Czarnogóra $\left.{ }^{*}\right)$ & II & II \\
\hline Słowacja & II & II \\
\hline Słowenia & II & II \\
\hline Hiszpania & I & I \\
\hline Szwecja & III & III \\
\hline Szwajcaria & II & II \\
\hline Wielka Brytania & I & III \\
\hline
\end{tabular}

*) norma PN-EN 13129-1:2004 [4] podaje dane dla państwa Serbia i Czarnogóra, jednak w 2006 r. nastapit rozpad tej federacji $i$ powstanie dwóch oddzielnych państw, co zostało uwzględnione $w$ tabeli 4.

ciepła od urządzeń pokładowych. Rozpatruje się przypadek ruchu pojazdu z największą prędkością konstrukcyjną, dla której odpływ ciepła z kabiny na skutek przenikania jest największy. Łączne straty ciepła można wyrazić następującym wzorem:

$$
Q_{\text {str }}=Q_{\text {przen }}+Q_{\text {wen }}
$$

gdzie:

$Q_{\text {str }}$ - łączne straty ciepła w kabinie [kW],

$Q_{\text {przen }}$ - straty ciepła na skutek przenikania $[\mathrm{kW}]$,

$Q_{\text {wen }}-$ straty ciepła na skutek wentylacji kabiny [kW].

\subsection{Straty ciepła na skutek przenikania}

Straty wynikające z przenikania ciepła przez ściany kabiny maszynisty wyraża się następującym wzorem:

$$
Q_{\text {przen }}=k_{N} \cdot F_{N} \cdot\left(T_{w}-T_{z}\right)
$$


gdzie:

$k_{N}-$ współczynnik przenikania ciepła [W/m² $\left.\mathrm{K}\right]$,

$F_{N}$ - powierzchnia przenikania ciepła $\left[\mathrm{m}^{2}\right]$.

Powierzchnię przenikania ciepła $\mathrm{w}$ kabinie stanową ściany: czołowa, boczne, tylna oraz dachowa, pomijana jest jednak powierzchnia podłogi kabiny maszynisty.

W normie PN-EN 14813-1:2006 [5] określono zalecane maksymalne współczynniki przenikania ciepła $k_{N}$ dla obu kategorii kabin maszynisty w porze zimowej. Zostało to przedstawione w tabeli 5.

Maksymalne dopuszczalne współczynniki przenikania ciepła $k_{N} \mathbf{w}$ kabinie maszynisty

Tabela 5

\begin{tabular}{|c|c|c|}
\hline & \multicolumn{2}{|c|}{$\begin{array}{c}\text { Max. dopuszczalny wsp. przenikania } \\
k_{N}\left[\mathrm{~W} / \mathrm{m}^{2} \mathrm{~K}\right]\end{array}$} \\
\hline Strefa & Kategoria A & Kategoria B \\
\hline I & 2,3 & 3,5 \\
\hline II & 1,9 & 3,0 \\
\hline III & 1,6 & 2,5 \\
\hline
\end{tabular}

Podczas konstruowania nowej lub modernizowanej kabiny maszynisty należy w taki sposób dobrać materiały izolacyjne aby uzyskać współczynnik $\mathrm{k}_{\mathrm{N}}$ nie większy od dopuszczalnego $\mathrm{w}$ danej strefie temperaturowej. Otrzymany współczynnik przyjmuje się do dalszych obliczeń. Dla przykładowej kabiny straty ciepła wynikające z przenikania i przy założeniu maksymalnego dopuszczalnego współczynnika przenikania ciepła wynoszą:

$$
\begin{aligned}
& Q_{\text {pren }}=1,6 \frac{\mathrm{W}}{\mathrm{m}^{2} \cdot \mathrm{K}} \cdot 27,5 \mathrm{~m}^{2} . \\
& \cdot\left(22{ }^{\circ} \mathrm{C}-\left(-40^{\circ} \mathrm{C}\right)\right)=2,728 \mathrm{~kW}
\end{aligned}
$$

\subsection{Straty ciepła na skutek wentylacji}

Straty ciepła na skutek wentylacji można wyrazić następującym wzorem:

$$
Q_{\text {wen }}=W_{\text {pow }} \cdot c_{p} \cdot\left(T_{w}-T_{z}\right)
$$

gdzie:

$$
\begin{aligned}
& \mathrm{W}_{\text {pow }}-\text { masa wymienianego powietrza }[\mathrm{kg} / \mathrm{s}] \\
& \mathrm{c}_{\mathrm{p}}-\text { ciepło właściwe powietrza przy stałym ciśnie- } \\
& \text { niu }[\mathrm{J} / \mathrm{kg} . \mathrm{K}] \\
& \mathrm{c}_{\mathrm{p}}=1000 \mathrm{~J} / \mathrm{kg} \mathrm{K} .
\end{aligned}
$$

W celu obliczenia masy wymienianego powietrza należy wyznaczyć objętość powietrza wymienianą w ciągu 1 sekundy oraz wziąc pod uwage gęstość powietrza w kabinie, którą należy odczytać z wykresu zależności gęstości powietrza $\left(\rho_{\text {pow }}\right)$ od temperatury, przy założeniu ciśnienia normalnego 1013,25 hPa. Ilość wymienianego powietrza oblicza się ze wzoru:

$$
W_{\text {pow }}=\frac{V_{\min }}{3600} \cdot \rho_{\text {pow }}
$$

Gęstość powietrza w kabinie, która dla ciśnienia 1013,25 hPa i temperatury wnętrza przykładowej kabiny równej $22{ }^{\circ} \mathrm{C}$ wynosi $\rho_{\text {pow }}=1,197 \mathrm{~kg} / \mathrm{m}^{3}$. Ilość wymienianego powietrza przy założeniu 2-osobowej obsługi, oblicza się ze wzoru:

$$
W_{\text {pow }}=\frac{2 \cdot 30 \frac{\mathrm{m}^{3}}{\mathrm{~h}}}{3600} \cdot 1,197 \frac{\mathrm{kg}}{\mathrm{m}^{3}} \approx 0,01995 \mathrm{~kg}
$$

Dla przyjętych danych straty ciepła na skutek wentylacji wynoszą:

$$
\begin{aligned}
& Q_{\text {wen }}=0,01995 \mathrm{~kg} \cdot 1000 \frac{\mathrm{J}}{\mathrm{kg} \cdot \mathrm{K}} . \\
& .\left(22^{\circ} \mathrm{C}-\left(-40^{\circ} \mathrm{C}\right)\right) \approx 1,237 \mathrm{~kW}
\end{aligned}
$$

Łączne straty ciepła w przykładowej kabinie maszynisty wynoszą:

$$
Q_{\text {str }}=Q_{\text {pren }}+Q_{\text {wen }}=2,728 \mathrm{~kW}+1,237 \mathrm{~kW} \approx 3,97 \mathrm{~kW}
$$

\section{Obliczenia cieplne kabiny maszynisty dla urzą- dzeń klimatyzacji}

\subsection{Lączny zysk ciepła}

W celu obliczenia łącznego zysku ciepła w kabinie maszynisty należy wziąć pod uwagę czynniki wewnątrz kabiny (emisję ciepła przez człowieka oraz urządzenia pokładowe) oraz oddziaływanie zewnętrzne. Przyjmuje się, że pojazd nie znajduje się w ruchu, co powoduje najmniejsze straty ciepła w wyniku przenikania.

Łączny zysk ciepła wyraża się następującym wzorem:

$$
Q_{K}=Q_{I}+Q_{A}-Q_{w e n}
$$

gdzie:

$$
\begin{array}{ll}
\mathrm{Q}_{\mathrm{K}}- & \begin{array}{l}
\text { tączny zysk ciepła w kabinie }[\mathrm{kW}], \\
\mathrm{Q}_{\mathrm{I}}-
\end{array} \\
& \begin{array}{l}
\text { zysk ciepła na skutek oddziaływań } \\
\text { wewnętrznych w kabinie }[\mathrm{kW}],
\end{array} \\
\mathrm{Q}_{\mathrm{A}}- & \begin{array}{l}
\text { zysk ciepła na skutek oddziaływań } \\
\text { zewnętrznych }[\mathrm{kW}],
\end{array} \\
\mathrm{Q}_{\mathrm{wen}}-\quad \begin{array}{l}
\text { strata ciepła na skutek wentylacji } \\
{[\mathrm{kW}] .}
\end{array}
\end{array}
$$

Stratę ciepła na skutek wentylacji oblicza się w sposób analogiczny jak w przypadku obliczeń cieplnych dla urządzeń grzewczych kabiny (patrz wzór 4).

\subsection{Wewnętrzny zysk ciepła}

Wewnętrzny zysk ciepła wyraża się następującym wzorem: 
gdzie:

$$
Q_{I}=Q_{M}+Q_{B}+Q_{R}
$$

$\mathrm{Q}_{\mathrm{M}}$ - zysk ciepła pochodzący od operatorów (maszynistów) [kW],

$\mathrm{Q}_{\mathrm{B}}$ - zysk ciepła pochodzący od urządzeń pokładowych [kW],

$\mathrm{Q}_{\mathrm{R}}$ - zysk ciepła pochodzący od przestrzeni o podwyższonej temperaturze np. od przegrody komory silnika spalinowego [kW].

Ciepło emitowane przez zdrowego człowieka można odczytać z wykresu, przedstawionego na rys. 1 .

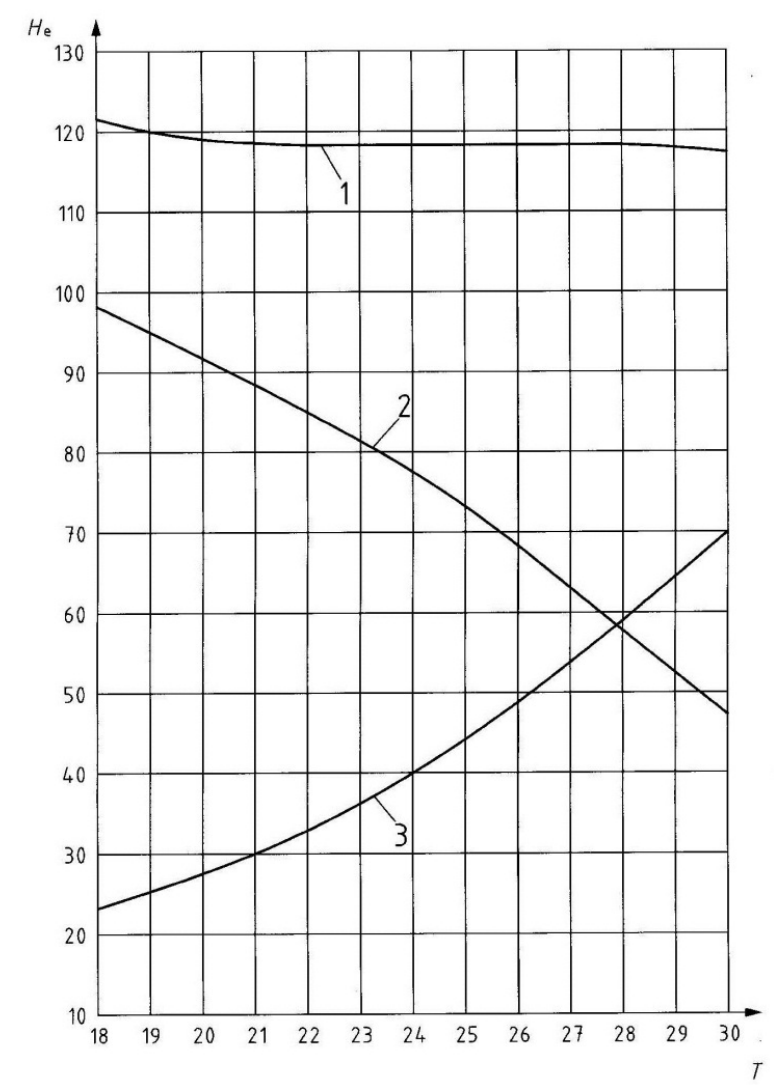

Rys. 1. Emisja ciepła przez ciało człowieka w zależności od temperatury otoczenia wg PN-EN 14813-1:2006 [6]

Oznaczenia: $H_{e}$-emitowane ciepto [W], T-temp. otoczenia $\left[{ }^{\circ} \mathrm{C}\right]$, 1 - ciepło calkowite, 2 - ciepto rzeczywiste (oddawane przez skóre), 3 - ciepło wtórne (w postaci odparowanej wilgoci)

Jak wynika $\mathrm{z}$ wykresu na rys. 1., zdrowy człowiek w przedziale temperatur $21 \div 28^{\circ} \mathrm{C}$ wydziela w przybliżeniu $120 \mathrm{~W}$. Nie ma to dużego wpływu na zysk ciepła w kabinie maszynisty, jednak dla przestrzeni pasażerskiej, w szczególności dla pojazdów komunikacji podmiejskiej, w których zagęszczenie pasażerów jest największe, zysk ciepła może osiagać wartości znaczące.

Dla obliczeń przykładowej kabiny przyjmuje się:

$$
\begin{aligned}
& \mathrm{Q}_{\mathrm{M}}=2 \cdot 0,12=0,24 \mathrm{~kW} \\
& \mathrm{Q}_{B}=0,2 \mathrm{~kW} \\
& \mathrm{Q}_{\mathrm{R}}=0 \mathrm{~kW}
\end{aligned}
$$

Uwzględniając powyższe wartości, wewnętrzny zysk ciepła dla przykładowej kabiny wynosi:

$$
Q_{I}=0,24 k W+0,2 k W=0,44 k W
$$

\subsection{Zewnętrzny zysk ciepła}

Zewnętrzny zysk ciepła wyraża się następującym wzorem:

$$
Q_{A}=Q_{W 1}+Q_{W 2}+Q_{T}+Q_{S}
$$

gdzie:

$\mathrm{Q}_{\mathrm{A}}$ - zewnętrzny zysk ciepła [kW],

$\mathrm{Q}_{\mathrm{W} 1}-$ zysk ciepła od ścian nasłonecznionych $[\mathrm{kW}]$,

$\mathrm{Q}_{\mathrm{W} 2}$ - zysk ciepła od ścian nienasłonecznionych $[\mathrm{kW}]$,

$\mathrm{Q}_{\mathrm{T}}-$ zysk ciepła od szyb $[\mathrm{kW}]$,

$\mathrm{Q}_{\mathrm{S}}$ - zysk ciepła od szyby nasłonecznionej (czołowej) [kW].

\subsection{Zysk ciepła od ścian nasłonecznionych i niena- słonecznionych}

Przez pojęcie ścian nasłonecznionych należy rozumieć powierzchnię przednią, boczną oraz dach kabiny z wyłączeniem szyb, natomiast przez pojęcie ścian nienasłonecznionych należy rozumieć wszystkie pozostałe powierzchnie z wyłączeniem szyb.

W celu obliczenia zysku ciepła od ścian konieczne jest wyznaczenie tzw. temperatury obliczeniowej, uwzględniającej nagrzewanie się ścian wskutek działania wysokiej temperatury powietrza. Wspomnianą temperaturę można obliczyć za pomocą poniższego wzoru:

$$
\text { gdzie: } T_{o b l}=T_{z}+\frac{A \cdot I}{\alpha_{z}}
$$

A - współczynnik absorpcji, zależny od koloru ściany [-],

I - natężenie promieniowania słonecznego $\left[\mathrm{W} / \mathrm{m}^{2}\right]$,

$\alpha_{z}-$ współczynnik przyjmowania ciepła na powierzchni ścian zewnętrznych $\left[\mathrm{W} / \mathrm{m}^{2} \Re\right.$ ]

Współczynnik absorpcji dla najmniej korzystnego wariantu malatury kabiny w ciemnych kolorach zewnętrznych wyniesie: $\mathrm{A}=0,9$. [3] 
Natężenie promieniowania słonecznego przyjmuje się w zależności od przynależności danego państwa Europy do strefy temperaturowej w okresie letnim. Wartości natężenia promieniowania słonecznego dla różnych stref temperaturowych podano w tabeli 6 .

Wartości natężenia promieniowania słonecznego w zależności od strefy temperaturowej

Tabela 6

\begin{tabular}{|c|c|}
\hline Strefa & $\begin{array}{c}\text { Natężenie promieniowania sło- } \\
\text { necznego } I\left[\mathrm{~W} / \mathrm{m}^{2}\right]\end{array}$ \\
\hline I & 800 \\
\hline II & 700 \\
\hline III & 600 \\
\hline
\end{tabular}

Współczynnik przyjmowania ciepła na powierzchni ścian zewnętrznych dla pojazdu będącego w stanie spoczynku wynosi: $\alpha_{z}=20 \mathrm{~W} / \mathrm{m}^{2} \mathbb{K}$ [3].

W celu obliczenia zysków ciepła od ścian nasłonecznionych oraz nienasłonecznionych należy skorzystać z następujących zależności:

$$
\begin{aligned}
& Q_{W 1}=F_{S N i} \cdot k_{N} \cdot\left(T_{o b l}-T_{W}\right) \\
& Q_{W 2}=F_{N i} \cdot k_{N} \cdot\left(T_{z}-T_{W}\right)
\end{aligned}
$$

gdzie:

$\mathrm{F}_{\mathrm{SNi}}$ - całkowita powierzchnia ścian nasłonecznionych $\left[\mathrm{m}^{2}\right]$,

$\mathrm{F}_{\mathrm{Ni}}$ - całkowita powierzchnia ścian nienasłonecznionych $\left[\mathrm{m}^{2}\right]$,

$\mathrm{k}_{\mathrm{N}} \quad-$ współczynnik przenikania ciepła $\left[\mathrm{W} / \mathrm{m}^{2} \mathrm{~K}\right]$.

Zakłada się identyczny współczynnik przenikania ciepła dla wszystkich ścian kabiny. Dla przykładowej kabiny maszynisty zysk ciepła od ścian nasłonecznionych i nienasłonecznionych, przy uwzględnieniu powyższych danych, wynosi:

$$
\begin{gathered}
T_{\text {obl }}=35^{\circ} \mathrm{C}+\frac{0,9 \cdot 700 \frac{\mathrm{W}}{\mathrm{m}^{2}}}{20 \frac{\mathrm{W}}{\mathrm{m}^{2} \cdot \mathrm{K}}} \approx 67^{\circ} \mathrm{C} \\
Q_{W 1}=12,15 \mathrm{~m}^{2} \cdot 1,6 \frac{\mathrm{W}}{\mathrm{m}^{2} \cdot \mathrm{K}} \cdot\left(67^{\circ} \mathrm{C}-28^{\circ} \mathrm{C}\right)=0,758 \mathrm{~kW} \\
Q_{W 2}=15,65 \mathrm{~m}^{2} \cdot 1,6 \frac{\mathrm{W}}{\mathrm{m}^{2} \cdot \mathrm{K}} \cdot\left(35^{\circ} \mathrm{C}-28^{\circ} \mathrm{C}\right)=0,175 \mathrm{~kW}
\end{gathered}
$$

\subsection{Zysk ciepla od szyb}

Zysk ciepła od szyb w kabinie można wyrazić za pomocą następującej zależności:

$$
Q_{T}=F_{s z} \cdot k_{s z} \cdot\left(T_{z}-T_{w}\right)
$$

gdzie:

$\mathrm{F}_{\mathrm{sz}}$ - powierzchnia wszystkich szyb w kabinie $\left[\mathrm{m}^{2}\right]$,

$\mathrm{k}_{\mathrm{sz}}$ - współczynnik przenikania ciepła przez szyby $\left[\mathrm{W} / \mathrm{m}^{2} \mathrm{~K}\right]$.
Współczynnik przenikania ciepła $\mathrm{k}_{\mathrm{sz}}$ jest podawany przez producenta danej szyby. Dla danych przykładowej kabiny $\mathrm{i}$ przyjmując $\mathrm{k}_{\mathrm{sz}}=6 \mathrm{~W} / \mathrm{m}^{2} \mathrm{~K}$ otrzymuje się:

$Q_{T}=4,7 \mathrm{~m}^{2} \cdot 6 \frac{\mathrm{W}}{\mathrm{m}^{2} \cdot \mathrm{K}} \cdot\left(35^{\circ} \mathrm{C}-28^{\circ} \mathrm{C}\right)=0,197 \mathrm{~kW}$

\subsection{Zysk ciepła od szyby nasłonecznionej (przed- niej)}

Zysk ciepła od przedniej szyby nasłonecznionej można przedstawić za pomocą następującego równania:

$$
Q_{s}=\left[F_{s z N} \cdot I \cdot a+\left(F_{s z}-F_{s z N}\right) \cdot I_{R}\right] \cdot b
$$

gdzie:

$\mathrm{F}_{\mathrm{szN}}$ - powierzchnia szyby nasłonecznionej $\left[\mathrm{m}^{2}\right]$,

I - natężenie promieniowania słonecznego $\left[\mathrm{W} / \mathrm{m}^{2}\right]$,

a - współczynnik czystości atmosfery [-],

$\mathrm{I}_{\mathrm{R}}$ - natężenie promieniowania słonecznego rozproszonego $\left[\mathrm{W} / \mathrm{m}^{2}\right]$,

b - współczynnik absorpcji promieniowania szyb [-].

Współczynnik czystości atmosfery określa w jaki sposób atmosfera wpływa na osłabienie natężenia promieniowania słonecznego. Wynosi on 1,15 dla atmosfery czystej (np. terenów rolniczych), 1 dla atmosfery dużego miasta oraz 0,87 dla atmosfery przemysłowej [3].

Natężenie promieniowania słonecznego rozproszonego zależy od danej pory dnia. Maksymalna wartość natężenia promieniowania słonecznego rozproszonego dla szerokości geograficznej $50^{\circ} \mathrm{W}$ okresie maj-lipiec wynosi: $I_{R}=763 \mathrm{~W} / \mathrm{m}^{2}[3]$.

Współczynnik absorpcji promieniowania szyb zależy w sposób bezpośredni od zastosowanych w pojeździe szyb. Zestawienie różnych typów szyb wraz z bezwymiarowymi współczynnikami absorpcji promieniowania przedstawiono $\mathrm{w}$ tabeli 7 .

Zależność współczynnika absorpcji promieniowania od rodzaju zastosowanych szyb

Tabela 7

\begin{tabular}{|c|c|}
\hline Rodzaj szyb & Współczynnik b [-] \\
\hline Szyby zwykłe pojedyncze & 1,0 \\
\hline Szyby zwykłe podwójne & 0,9 \\
\hline Szyby absorbujące & 0,7 \\
\hline Szyby refleksyjne & 0,6 \\
\hline $\begin{array}{c}\text { Szyby refleksyjne z warstwą tlenków } \\
\text { metali }\end{array}$ & 0,5 \\
\hline $\begin{array}{c}\text { Szyby refleksyjne z warstwą tlenków } \\
\text { metali szlachetnych }\end{array}$ & 0,4 \\
\hline
\end{tabular}


$Q_{s}=\left[3,5 \mathrm{~m}^{2} \cdot 700 \frac{\mathrm{W}}{\mathrm{m}^{2}} \cdot 1+\left(4,7 \mathrm{~m}^{2}-3,5 \mathrm{~m}^{2}\right) \cdot 763 \frac{\mathrm{W}}{\mathrm{m}^{2}}\right] \cdot 0,6=2,02 \mathrm{~kW}$

Łączny zysk ciepła dla przykładowej kabiny wyniesie:

$Q_{K}=0,44+0,758+0,172+0,197+2,02=3,567 \mathrm{~kW}$

Przyjmując, że pojazd będzie poruszał się głównie w dużych miastach i zostaną zabudowane w nim szyby refleksyjne, otrzymuje się dla przykładowej kabiny:

\section{Wnioski}

W artykule zaprezentowano sposób obliczania wartości strat oraz zysków ciepła w kabinie maszynisty pojazdu szynowego. Przedstawiono poszczególne składowe obliczanych wartości ciepła. Powołano się na obowiązujące w opisywanym zakresie normy europejskie. Przedstawiony w artykule sposób postępowania może stanowić pomoc przy projektowaniu i doborze urządzeń grzewczych oraz klimatyzacyjnych do nowych oraz modernizowanych kabin pojazdów szynowych.

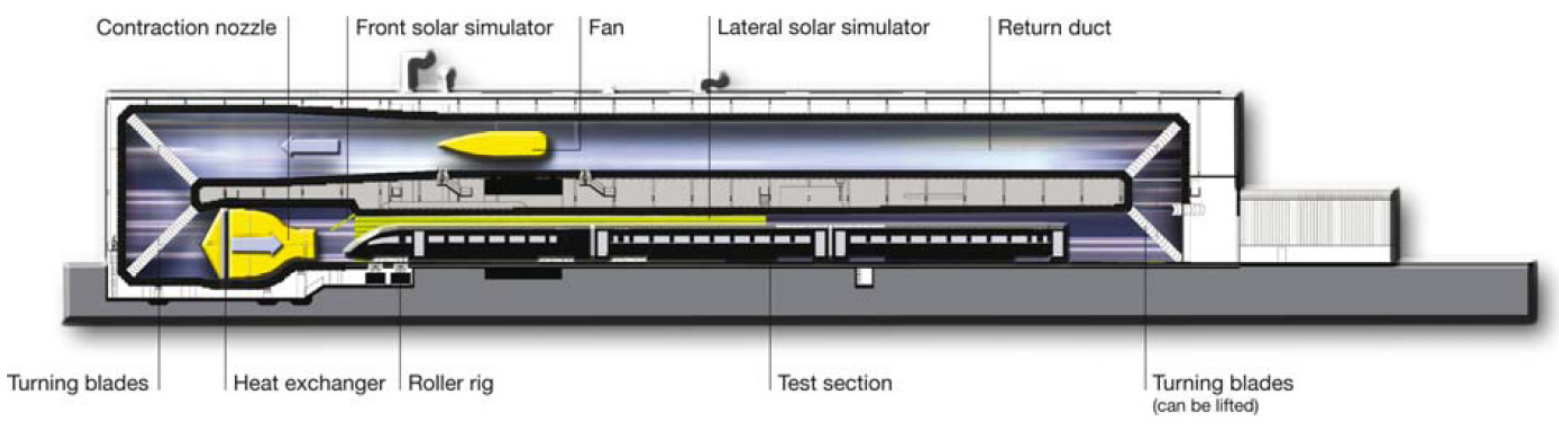

Rys. 2. Przekrój tunelu klimatycznego we Wiedniu [7]

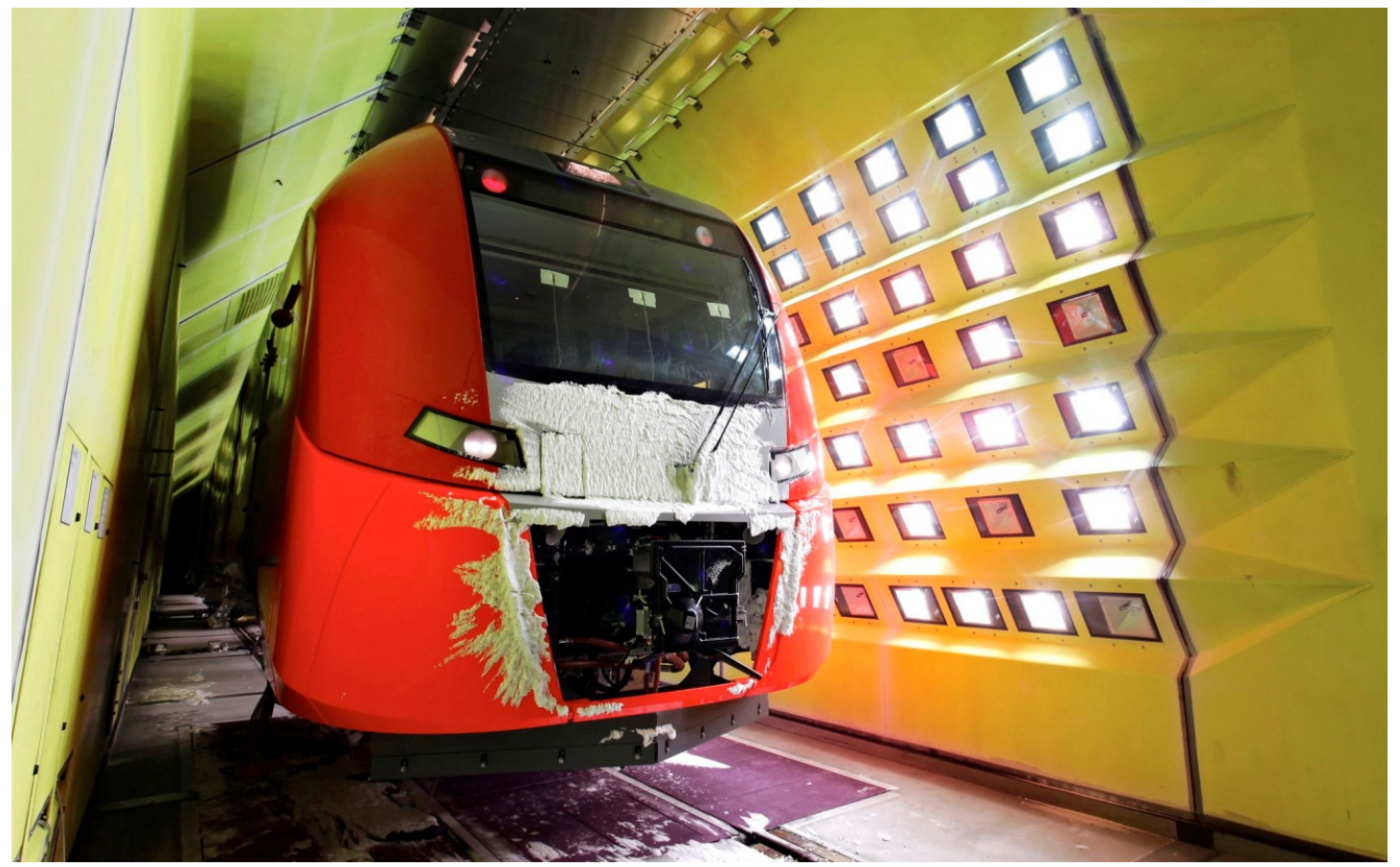

Rys. 3. Elektryczny zespół trakcyjny podczas badań w tunelu klimatycznym we Wiedniu [8] 
Przy obliczeniach całkowitego zysku ciepła największy udział ma zysk ciepła od szyby nasłonecznionej. W celu redukcji ilości ciepła wnikającego przez szybę nasłonecznioną należy stosować szyby przednie o najmniejszym możliwym współczynniku absorpcji promieniowania. Umożliwi to dobór urządzenia klimatyzacyjnego o mniejszej mocy chłodniczej, co pozwoli na redukcję całkowitych kosztów konstrukcji i eksploatacji pojazdu.

Przedstawione $\mathrm{w}$ artykule obliczenia mają charakter teoretyczny, a ich celem jest ukazanie strat oraz zysków ciepła dla danego przypadku kabiny maszynisty. Obliczone wartości strat (zysków) ciepła są minimalnymi wartościami ciepła, które należy doprowadzić (odprowadzić) do wnętrza kabiny w celu utrzymania $\mathrm{w}$ niej jednakowej temperatury. W celu podwyższenia lub obniżenia temperatury wnętrza należy dobierać urządzenia o odpowiednio większych mocach grzewczych lub chłodniczych, przy zachowaniu wymagań normatywnych, ukazanych w rozdziale 2 niniejszego artykułu.

Weryfikację zgodności zastosowanych rozwiązań $\mathrm{z}$ przeprowadzonymi obliczeniami należy przeprowadzić przed uzyskaniem przez pojazd dopuszczenia do ruchu. Badania wykonuje się zgodnie z treścią norm europejskich. Wymagania dla urządzeń grzewczych oraz klimatyzacyjnych zostały podane w rozdziale 2. artykułu. W przypadku, gdy pojazd będzie poruszać się $\mathrm{w}$ ekstremalnych warunkach atmosferycznych, weryfikację zastosowanych rozwiązań można przeprowadzić w specjalnych tunelach klimatycznych, dedykowanych pojazdom szynowym. Największy w Europie tunel klimatyczny znajduje się we Wiedniu. Przekrój tej konstrukcji został przedstawiony na rys. 2
W przedstawionym tunelu klimatycznym, należącym do firmy Rail Tec Arsenal Fahrzeugversuchsanlage $\mathrm{GmbH}$ możliwa jest symulacja zarówno ekstremalnych warunków zimowych, jak i intensywnego nasłonecznienia. $W$ tunelu można uzyskać temperatury z zakresu od $-45^{\circ} \mathrm{C}$ do $+60^{\circ} \mathrm{C}$. Zainstalowane wentylatory są $\mathrm{w}$ stanie rozpędzić powietrze w tunelu do $300 \mathrm{~km} / \mathrm{h}$. Zabudowane reflektory zapewniają dopływ energii świetlnej, stanowiącej odpowiednik natężenia promieniowania słonecznego o maksymalnej wartości $1000 \mathrm{~W} / \mathrm{m}^{2}$. Na rys. 3. przedstawiono przykładowy pojazd, będący $\mathrm{w}$ trakcie badań w tunelu klimatycznym.

Przedstawiony tunel klimatyczny służy również do badania poprawności działania urządzeń zainstalowanych na pojeździe, jak np. sprzęgi samoczynne czy też wycieraczki.

\section{Literatura}

[1] Dyrektywa 2008/57/WE - Techniczna specyfikacja interoperacyjności - Podsystem „,Tabor kolejowy - lokomotywy i tabor pasazerski" systemu kolei konwencjonalnych

[2] Karta UIC-553, Wentylacja, ogrzewanie i klimatyzacja wagonów pasażerskich, $2003 r$.

[3] Kwaśniowski S. Ogrzewanie, wentylacja i klimatyzacja w pojazdach mechanicznych, Oficyna Wydawnicza Politechniki Wrocławskiej, Wrocław 1995

[4] PN-EN 13129-1:2004 Kolejnictwo - Klimatyzacja pojazdów linii gtównych,część 1: parametry komfortu

[5] PN-EN 14813-1:2006 Kolejnictwo - Klimatyzacja kabin maszynisty - część 1: parametry komfortu

[6] PN-K 11010:1994 Tabor kolejowy - Instalacja klimatyzacji i ogrzewania nawiewnego wagonu - wymagania ogólne

[7] Materiaty reklamowe firmy Rail Tec Arsenal Fahrzeugversuchsanlage $\mathrm{GmbH}$

[8] Materialy prasowe firmy Siemens: www.siemens.com 